\title{
Atmospheric Music Fit As A Driver Of Shopper Store Evaluations And Their Behavioral Responses
}

Irena Vida, University of Ljubljana, Slovenia

\begin{abstract}
This study examines effects of background music fit on consumer evaluative and behavioral responses across two distinct retail formats. Existing body of theoretical and empirical research serves as a basis for development of research hypotheses, which are subsequently tested using store-intercept data of adult shoppers. Covariance analyses reveal insightful implications of study findings for future research and management of retail brands.
\end{abstract}

\section{INTRODUCTION}

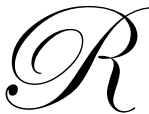

etailers and other service organizations increasingly recognize that the physical characteristics of their trading spaces represent an opportunity to communicate with their target market, create in-store experiences as means of competitive positioning, and build their brands. In creating the right atmosphere in their facilities, firms can appeal to various visual, aural, olfactory and tactile store elements. The use of colors, lightning, sounds, scents and visual images are particularly effective in retail stores and service establishments as they affect consumers' moods and emotions, which in turn play a key role in end-user satisfaction (Gorn et al., 1993; Machleit and Mantel, 2001).

In recent decades, the impact of atmospherics on consumers' behavioral responses has attracted attention among academic researchers. Music, in particular, has attracted noteworthy interest among marketing researchers, because of its proven effects on consumers as well as relatively low costs involved in music implementation in the retail setting (Garlin and Owen, 2006). However, the specific effects of in-store music on shoppers' behavioral responses are often misunderstood, and its effects on retail branding and image development underestimated (Beverland et al., 2006). These gaps, along with the fact that the majority of existing research on atmospheric effects has been conducted in mature retail markets, i.e., USA, Canada and Australia, prompted us to examine the impact of atmospherics on consumer behavior in a novel socio-cultural context. The literature in cross-cultural marketing has established the need to validate consumer behavior models and theories developed in the West, and establish their degree of generalizability and boundary conditions in international settings (Steenkamp and Burgess, 2002). Hence, the goal of this study was to examine the role of music fit with the overall retail image on consumer evaluative and behavioral responses in an emerging, high growth retail market. Moreover, music fit effects were empirically investigated in two distinct retail formats. Consistently with the literature, music fit is defined in this study as a congruency between music and other atmospheric and retail image variables (Baker et al., 2002; Garlin and Owen, 2006).

\section{LITERATURE REVIEW ON THE ATMOSPHERICS-BEHAVIOR RELATIONS}

Probably the most commonly used theoretical paradigm in empirical research investigating the impact of atmospherics originates in environmental psychology. The M-R model (Mehrabian and Russell, 1974) examines individuals' reactions to environmental cues through mediating nonverbal responses related to three dimensions: Pleasure, Arousal and Dominance (PAD). Pleasures refers to the extent that a specific environmental cue is enjoyable vs. not enjoyable, and Arousal to the extent that it stimulates the individual, i.e., it results in approach vs. avoidance behaviors. Dominance, the third dimension in the M-R model relates to whether a person feels "in" 
control vs. "under" control in the environment. The M-R model was tested in a retail setting by Donovan and Rossiter (1982), who confirmed the dimensions of pleasure and arousal were significant mediators between environmental stimuli and consumer responses. They also identified difficulties in measuring effects of store atmospheric elements, claiming that environmental stimuli elicit merely transient emotional states, which are difficult to recall and articulate.

Having introduced the concept of "servicescapes", Bitner (1992) developed one of the most comprehensive models investigating the impact of the physical environment on individuals' behavioral responses in service organizations. She proposes that a person's perception of environmental conditions such as ambient physical characteristics, space layout and furnishings as well as symbols and artifacts will affect physiological, cognitive and emotional responses of both customers and staff alike. These will, in turn, affect their attitudes and behaviors in services settings. Similarly, Baker et al. (2002) investigated the effects of multiple environmental cues specifically in a product retailing setting, and proposed that design, ambient and social dimensions of the store environment and consumer perceptions of merchandise, value, service quality, effort and psychic costs affect store patronage decisions.

A number of previous empirical studies applied the aforementioned models of environment-behavior relationship (e.g., Chebat and Michon, 2003; Hui and Dube, 1997; Spangenberg et al., 2006). More recently, Beverland et al. (2006) advanced a conceptual model specifically focusing on effects of the music fit with the store/product brand perception on the customers' cognitive and emotional processes, which, in turn, affect shoppers' behavioral outcomes, including the amount of time spent in the store, satisfaction, willingness to pay and purchase intention. This most recent qualitative work on in-store-music/brand fit is particularly applicable to this study. In subsequent sections of this paper, findings of existing empirical work on the impact of music are presented as they provide a basis for the research hypotheses.

\section{Hypotheses Development: Music Effects On Evaluative And Behavioral Responses}

In their study of music in a retail setting, Hui and Dube (1997) found that the in-store music resulted in more positive emotions, and that positive perceptions of the music resulted in a more positive approach behavior toward the organization. Similarly, Dube and Morin (2001) examined the impact of in-store music pleasure intensity, and determined that attitude toward the servicescape (retail environment), attitude toward sales personnel and overall store evaluation were more positive in the high-pleasure intensity scenario. Furthermore, other studies confirm that the feelings of pleasure derived from the atmospheric music can enhance shoppers' evaluation of the store and its elements (e.g., Gorn et al., 1993; Yalch and Spangenberg, 2000). However, several authors also caution that atmospheric music is effective only when it is in congruency with other environmental stimuli such as color, scents, layout, in-store-fixtures, and a retailer's marketing mix variables (Mattila and Wirtz; 2001; Morrison and Beverland, 2003).

Other studies examined the impact of background music on temporal dimensions of in-store behavior and on shopper expenditures. For example, Herrington (1996) studied the role of background music in a supermarket setting, and found that shopping time and expenditures increased with the level of preference for the music, but that music dimension such as the tempo or volume did not have significant impact. On the other hand, Caldwell and Hibbert (2002) found that both music tempo and music preference were significantly related to the time spent in a restaurant, but concluded that only the time spent in the restaurant had a significant effect on the total amount customers spent.

With respect to the music fit, it has been previously determined that various environmental cues need to match in order to enhance consumers' evaluations of and behaviors in the shopping experience. Hence, the effects of music fit are unlikely to have the same impact in different types of retail formats. Atmospheric music will play a different role in task-oriented shopping environments such as grocery stores than in retail formats that are patronized for recreational purposes such as shopping centers or specialty stores (Mattila and Wirtz, 2001). Retailers with somewhat narrowly defined target markets may be better able to take advantage of effectively manipulating atmospheric cues (i.e., music) than retail formats with broadly defined market segments, such as supermarkets 
(Herrington, 1996; Turley and Milliman, 2000). Against this theoretical and empirical work, we propose the following research hypotheses:

H1: $\quad$ The perceived music fit is positively related to shoppers' evaluative judgments of the store merchandise.

H2: Shoppers evaluation of the store merchandise is positively related to (a) time spent in the store, and $(b)$ consumer expenditures.

H3: $\quad$ The time spent in the store is positively related to shoppers' expenditures.

H4: Retail format will have a mediating effect on the relationship between the music fit and shoppers' evaluation of the store merchandise.

\section{RESEARCH METHODS}

Hypotheses were tested by collecting data via store-intercept method as shoppers were leaving the checkout counter at two large supermarkets and three specialty store retailers. Two hundred fifty nine shoppers declared having paid attention to the music and were willing to complete the questionnaire. These shoppers represented the study sample with a mean age of 31.9 years (SD of 12.6). Other demographic characteristics indicate the sample consisted of 59.5 percent females, over 60 percent with at least a high school level of education, and over 60 percent were employed or self-employed. While the two sub samples of respondents were comparable with respect to the gender structure, education and employment status, the supermarket sample was somewhat older as compared to the specialty store sample.

The research instruments consisted of questions related to demographics, time spent in the store (a selfreported measure) and their expenditures (based on shoppers' checkout receipts). Five-point semantic differential scales were used for measuring constructs merchandise evaluation and music fit (Dube and Morin, 2001; Mattila and Wirtz, 2001). Merchandise evaluation measure consisted of three items related to merchandise selection, quality of merchandise, merchandise presentation. The music fit construct, which was defined as the perceived congruency between the background music and various the elements of the retail image (Levy and Weitz, 2004), was calculated as an index (i.e., the unweighted sum of items scores). The mean time spent in the store for the total sample was 22.8 minutes with supermarket respondents having spent, on the average, notably longer time in the store (36.6 minutes) than the specialty stores' respondents (12.9 minutes). The mean for expenditures was 22.9 Euro for the total sample with the means of 37.2 Euro and 12.7 Euro for supermarkets and specialty stores, respectively.

\section{ANALYSES AND FINDINGS}

Structural Equations Modeling (SEM) with maximum likelihood estimation technique was used to test the hypotheses. Following Anderson and Gerbing's (1988) recommendations, the analysis was conducted in two steps. The latent variable included in the model (merchandise evaluation) was analyzed first, followed by the evaluation of a structural model in order to assess the hypothesized relationships among the constructs. The standardized loading of each indicator of the focal construct merchandise evaluation, the composite reliability index - $\rho f$ (Gerbing and Anderson, 1988) and the variance extracted - $\rho v c$ (Fornell and Larcker, 1981) all exhibit indices superior or very close to the reference values.

Once the latent construct reliability and convergent validity were established, the structural model was evaluated in order to test the hypothesized relationships between constructs. The fit indices indicate an outstanding conformance of the model to the data $\left(\chi^{2}=10.05\right.$, d.f. $8, \mathrm{p}=0.26$; GFI $=0.987$; NFI $=0.964 ; \mathrm{TLI}=0.985 ; \mathrm{CFI}=$ 0.992; RMSEA = 0.332). Results of hypotheses testing are presented in Table 1. While hypotheses H1a, H2a and H3 are verified, no support was found for the relationship between shoppers' evaluation of the merchandise and expenditures $(\mathrm{H} 2 \mathrm{~b})$. In order to test hypothesis $\mathrm{H} 4$ related to the moderating effect of retail format on the relationship between music fit and merchandise evaluation, a two-group analysis was performed. It consisted of constraining the parameter to be evaluated (the path coefficient) to be equal between the two groups (supermarkets and specialty stores). Then, the $\chi^{2}$ of this model was compared with a model where this constraint had been released. A non-significant difference in $\chi^{2}$ of 0.7 indicated no support for the hypothesis tested (significant at $\mathrm{p} \leq 0.05$ if $\Delta \chi^{2}>3.84$ with a difference in d.f. $=1$ ). 
Table 1: Results of Hypotheses Testing

\begin{tabular}{|c|c|c|c|c|c|}
\hline & Predictor Variable & Dependent Variable & $\begin{array}{c}\text { Stand. Path } \\
\text { Coefficient }\end{array}$ & $\begin{array}{c}\text { T value* } \\
\text { Hypothesis } \\
\text { Results }\end{array}$ \\
\hline H1 & Music fit & Merchandise evaluation & 0.40 & 4.81 & Supported \\
\hline H2a & Merchandise evaluation & Time & 0.29 & 3.69 & Supported \\
\hline H2b & Merchandise evaluation & Expenditures & 0.09 & 1.38 & Not supported \\
\hline H3 & Time & Expenditures & 0.53 & 9.61 & Supported \\
\hline H4 & \multicolumn{2}{|c}{ Retail format moderates the link: Music Fit and Merchandise Evaluation } & Not supported \\
\hline
\end{tabular}

* Significant at $\mathrm{p} \leq 0.05$ if $|\mathrm{t}| \geq 1.96$.

** Significant at $\mathrm{p} \leq 0.05$ if $\Delta \chi^{2}>3.84, \Delta$ d.f. $=1$

\section{DISCUSSION AND CONCLUSIONS}

In this study, it was found that the perception of music fit results in a positive experience for consumer who then evaluate in-store merchandise more favourably and, as a result, spend more time and money in the store. Findings that the music fit does not influence shoppers' behaviours directly (it does so only through the intermediation of the merchandise evaluation) is consistent with the premise of the $\mathrm{M}-\mathrm{R}$ model in that the effects of pleasure (the perceived music fit) on approach responses (shopping time) are mediated through evaluative judgments. On the other hand, the analyses failed to demonstrate a direct effect of merchandise evaluation on consumer expenditures, but only an indirect effect on this behavioural response through the time spent in the retail store. Previous empirical studies focusing on background music effects rarely considered music fit as the focal variable and seldom utilized covariance analyses in testing their hypotheses of music effects, which make direct comparisons of results more difficult (e.g., Garlin and Owen, 2006; Herrington, 1996; Mattila and Wirtz, 2001 ). Future examinations of store atmospheric effects will need to re-examine whether the time spent in the store is the only direct determinant of consumer expenditures.

Contrary to existing empirical evidence and managerial retail practice in mature markets (e.g., Embrey, 2004; Rubel, 1996) the findings do not support the notion that the impact of music fit on shoppers' merchandise evaluation tends to be more essential for some retail formats than for others. Having analysed consumer responses in two distinct retail formats, we found no differences in the effects of music fit on shoppers' merchandise evaluations between supermarket and specialty store formats. However, since these store types clearly address market segments with distinct socio-demographic characteristics, lifestyles, preferences and expectations, it is reasonable to expect that these targets also differ in their responses to environmental cues. In light of the findings, it is recommended that future studies examining the role of retail format and music fit on shoppers' evaluations include individuals' characteristics and shopping-related motives in the model (Machleit and Mantel, 2001; Turley and Milliman, 2000).

In addition to confirming the importance of achieving adequate music fit with the overall retail image, several implications for retail managers emerge. Our findings clearly identify that the time shoppers spend in the retail facility directly translates into the amount of money spent during their store visit. Interestingly, the data on the mean timings and expenditures in both retail formats seem to imply that on the average, each additional minute consumer spends in the retail store converts into an extra Euro spent. An obvious implication for the retail management is the need to understand the factors that contribute to the length of shopping time. Our findings suggest the primary driver of the desired behavioural outcomes is the music selection. Hence, if retailers wish to retain shoppers in their facilities and convert this time into sales performance, they need to enhance shoppers' sensory experience. In doing so, music selection should be in harmony with other in-store and brand marketing variables, and linked to strategic objectives, including target market and brand positioning (Morrison and Beverland, 2003). By testing the model of atmospheric music fit effects on consumer attitudinal and behavioural responses in a different socio-cultural context, it is hoped this study contributes to a better understanding of the extent to which existing consumer behaviour models are universally applicable to novel cultural contexts. Results of our model testing provide evidence of generalizability of consumer responses to music stimuli in a retail setting. Cognizance 
of these issues may be particularly useful to retailers interested in "exporting" their retail images to international markets (McGoldrick, 1998; Vida, 2000).

\section{REFERENCES}

1. Anderson, J. C. and Gerbing, D.W. (1988) Structural equation modeling in practice: A recommended two step approach, Psychological Bulletin, 103(3), pp. 411-423.

2. Baker, J., Parasurman, A., Dhruv, G. and Voss, G. (2002) The influence of multiple store environment cues on perceived merchandise value and patronage intentions, Journal of Marketing, 66(22), pp. 120-141.

3. Beverland, M., Chig Lim E.A., Morrison, M. and Teriovski, M. (2006) In-store music and consumer-brand relationships: Relational transformation following experiences of (mis)fit, Journal of Business Research, 59(9), pp. 982-989.

4. Bitner, M.J. (1992) The impact of physical surroundings on employee responses, Journal of Marketing, 56(2), pp. 57-71.

5. Caldwell, C. and Hibbert, S. A. (2002) The influence of music tempo and musical preference on restaurant patrons' behavior, Psychology \& Marketing, 19(11), pp. 895-917.

6. Chebat, J-C. and Michon, R. (2003) Impact of ambient odors on mall shopper' emotions, cognition and spending: A test of competitive causal theories, Journal of Business Research, 56(7), pp. 529-539.

7. Donovan, R.J. and Rossiter, J.R. (1982) Store atmosphere: An environmental psychology approach, Journal of Retailing, 58(1), pp. 34-57.

8. Dube, L. and Morin, S. (2001) Background music pleasure and store evaluation: Intensity effects and psychological mechanisms, Journal of Business Research, 54(2), pp. 107-113.

9. $\quad$ Embrey, A. (2004) The sound of music, Display \& Design Ideas, 16 (February), pp. 46-47.

10. Fornell, C. and Larcker, D.F. (1981) Evaluating structural equation models with unobserved variables and measurement error, Journal of Marketing Research, 28 (3), pp. 39-50.

11. Garlin, F.V. and Owen, K. (2006) Setting the tone with the tune: a meta-analytic review of the effects of background music in retail settings, Journal of Business Research, 59(6), pp. 755-764.

12. Gerbing, David W. and Anderson, J.C. (1988) An updated paradigm for scale development incorporating unidimensionality and its assessment, Journal of Marketing Research, 25(2), pp. 186-192.

13. Gorn G. J., Goldberg, M. E. and Basu, K. (1993) Mood, awareness and product evaluation, Journal of Consumer Psychology, 2(2), pp. 237-256.

14. Herrington, J. D. (1996) Effects of music in service environments: A field study, The Journal of Services Marketing, 10(2), pp. 26-51.

15. Hui, M. K. and Dube, L. (1997) The impact of music on consumers' reactions to waiting for services, Journal of Retailing, 73(1), pp. 87-104.

16. Levy, M. and Weitz, B. A. (2004) Retailing Management, 5th ed. (New York: The McGraw-Hill Companies, Inc.).

17. Machleit, K. A. and Mantel, S. P. (2001) Emotional response and shopping satisfaction: moderating effects of shopper attributions, Journal of Business Research, 54(2), pp. 97-106.

18. Mattila, A. S. and Wirtz, J. (2001) Congruency of Scent and music as a driver of in-store evaluations and behavior, Journal of Retailing, 77(2), pp. 273-289.

19. McGoldrick, P.J. (1998) Spatial and temporal shifts in the development of international retail images, Journal of Business Research, 42, pp. 189-196.

20. Mehrabian, A. and Russell, J. (1974) An Approach to Environmental Psychology (MIT press, Cambridge, MA).

21. Morrison, M. and Beverland, M. (2003) In search of the right in-store music, Business Horizons, 72(6), pp.77-82.

22. Rubel, C. (1996) Marketing with music, Marketing News, 30(17), pp. 1-2.

23. Spangenberg, E.R., Sprott, D.E., Grohmann, B. and Tracy, D.L. (2006) Gender-congruent ambient scent influences on approach and avoidance behaviors in a retail store, Journal of Business Research, 59(12), pp. 1281-1287.

24. Steenkamp, J-B.E-M. and Burgess, S.M. (2002) Optimum stimulation level and exploratory consumer behavior in an emerging consumer market, International Journal of Research in Marketing, 19, pp. 131-50. 
25. Turley, L.W. and Milliman, R.E. (2000) Atmospheric effects on shopping behavior: A review of the experimental evidence, Journal of Business Research, 49(2), pp. 193-211.

26. Vida, I. (2000) An empirical inquiry into international expansion of the United States retailers, International Marketing Review, 17(4/5), pp. 454-475.

27. Yalch, R. F. and Spangenberg, E. R. (2000) The effects of music in a retail setting on real and perceived shopping times, Journal of Business Research, 49(2), pp. 139-147.

\section{NOTES}

